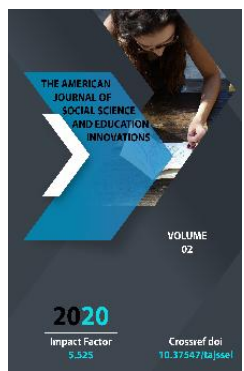

Journal Website: http://usajournalshub.c om/index,php/tajssei

Copyright: Original content from this work may be used under the terms of the creative commons attributes 4.0 licence.

\section{The Concept And Content Of Openness In The Activities Of Courts, And Its Importance In Administration Of Justice}

\author{
Muzaffarjon Mamasiddiqov \\ Head Of The Center Of The Academy Of General Prosecutor's Office Of The Republic Of \\ Uzbekistan, Doctor Of Legal Sciences, Professor, Uzbekistan \\ Erkin Sabirov \\ Independent Researcher The Academy Of General Prosecutor's Office Of The Republic Of \\ Uzbekistan, Uzbekistan
}

\title{
ABSTRACT
}

The concept and content of openness in the activities of courts, its importance in administration of justice, and conclusions are given on the difference, specific aspects of transparency in judicial proceedings and openness of the activities of the judicial authority

\section{KEYWORDS}

Judicial authority, transparency of judicial proceedings, openness of judicial activities, principles, transparency, public control, improvement

\section{INTRODUCTION}

It is known that judicial power is a separate and independent branch of state authority. Based on Article 11 of the Constitution of the Republic of Uzbekistan[1], the state authority is separated into legislative, executive and judicial powers. Therefore, the openness of the activities of the judicial authority, the provision of information on the rights and freedoms of citizens adopted by them, decisions related to their legitimate interests, the introduction of legal norms of public control over the activities of the judicial authority are one of the important issues in the conditions of further development of democratic reforms in our country.

The Actions Strategy[2] on the five priority areas of development of the Republic of Uzbekistan for 2017-2021, developed on the initiative of the President of the Republic of Uzbekistan Sh.M.Mirziyoyev, plays an 
important role in improving the efficiency of the tasks assigned to government agencies, establishing public control over their observance of human rights, freedoms and interests.

Strengthening the reliable protection of the rights and freedoms of citizens through the courts, introduction of modern information and communication technologies in courts, timely resolution of citizens' appeals and improving the efficiency and quality of justice, improving the procedural framework of administrative, criminal, civil and commercial proceedings are some of the important measures prescribed in the Actions Strategy.

The openness and transparency of judicial activity, ensuring transparency of judicial proceedings are considered one of the important components of the democratic procedural forms of judicial proceedings and serve as an important legal guarantee for the implementation of the law in the fair trial and the realization of the rights of the participants in the process. The principle of transparency of the case in court guarantees the substantive, legal and fair adoption of court decisions[3].

As the head of our state Sh.M.Mirziyoyev rightly noted in his Address to the Oliy Majlis, "... to date, no clear legal mechanisms have been created for effective public control (oversight) over the activities of state bodies. This prevents non-governmental non-profit organizations from objectively assessing the activities of government agencies and officials. Therefore, it is necessary to adopt the Law "On public control" in order to introduce effective and practical mechanisms for public control in public administration. In this regard, I propose to establish public councils under all government agencies. These public councils should act as a bridge to ensure the transparency of government agencies, connecting them directly with the population"[4].

\section{MATERIAL AND METHODS}

It is worth noting that the issue of openness of the activities of judicial power is distinguished by its peculiarities, compared to other branches of power. Therefore, article 113 of the Constitution of the Republic of Uzbekistan provides for the guarantee of open consideration of cases in all courts, as well as the norm of the possibility of hearing to cases in a closed session only in cases established by law. This constitutional norm has been developed in other legislative acts of our country. Consequently, according to Article 7 of the law of the Republic of Uzbekistan "On courts", it is envisaged that the cases will be considered open in all courts, consideration of cases in a closed session will be allowed only in cases specified in the law[5].

Article 12 of the Code of Civil Procedure states that all cases in courts are held in open hearings, except for cases where there is information related to state secrets, adoption secrets and in other cases provided by law. Also the article prescribes norms on the possibility of holding a closed court hearing in order to prevent the disclosure of information about the private lives of persons involved in the case, the confidentiality of correspondence and other secrets protected by law[6].

Article 11 of the Code of Economic Procedure also provides for open hearings in economic courts and for closed hearings if it is necessary to keep a state secret, trade secret or other secret protected by law[7].

Article 19 of the Code of Criminal Procedure provides for the transparency of criminal proceedings in all courts, except in cases of conflict of interest in the protection of state 
secrets, as well as in cases of sexual offenses[8].

Nevertheless, the openness and transparency of the judiciary is an important component of democratic procedural forms of litigation and serves as an important legal guarantee in ensuring the legitimacy of justice and the exercise of the rights of participants in the proceedings. Openness of the judiciary strengthens people's trust in the judiciary, the coverage of public cases in the media ensures public control over the judiciary and has an important educational value. Lawyer Sh.Sh.Shorakhmetov in his works also argued that the openness of cases allows citizens to get acquainted with the work of judges, to bring their activities under public control, and thus ensure the proper resolution of court cases[9]. According to Shorakhmetov, openness of cases allows citizens to get acquainted with the work of judges, to bring their activities under public control, and thus ensure the proper resolution of civil cases[10]. Transparency is considered one of the important components of the democratic procedural forms of judicial proceedings and serves as an important legal guarantee in the implementation of the law in the fair trial as well as in the realization of the rights of participants in the civil process. The principle of transparency of the case in court guarantees the substantive, legal and fair adoption of court decisions[11].

Ensuring the transparency of the judiciary strengthens people's trust in the judiciary, and the coverage of public cases in the media ensures public control of the judiciary and has an educational value. The literature also argues that openness of cases allows citizens to get acquainted with the work of judges, to bring their activities under public control, and thus to ensure the proper resolution of civil cases[12].
The purpose of the principle of transparency is to strengthen people's trust in judicial power. In addition, through the participation of the media public oversight is provided over the judicial proceedings. Therefore, the term transparency in the literature means that all persons, including representatives of the mass media, participate in the examination of civil cases in the courtroom[13]. Through the openness of the activities of the courts, an opportunity is created to see the material of civil cases in the media, in particular newspapers, magazines, radio, television broadcasting, with the participation of representatives of public organizations and labor communities in the proceedings.

In fact, the openness of judicial activity, making the public informed about the decisions in some categories of cases, is an integral part of the democratic legal state. Ensuring the transparency of the case, its openness and transparency for all, and the legality, fairness and fairness of court decisions shall serve to guarantee the norm that "all state bodies, public associations and officials of the Republic of Uzbekistan", enshrined in Article 30 of the Constitution of the Republic of Uzbekistan, should provide citizens with the opportunity to get acquainted with court decisions. It remains to be noted that the legality, justification and fairness of a court decision is in many respects more dependent on the openness (the ability of any person to get acquainted with a court decision) of court proceedings.

In this regard, Article 7 of the law of the Republic of Uzbekistan "On guarantees and freedom of obtaining information" dated April 24, 1997 obliges state bodies, self-government bodies of citizens, public associations, enterprises, institutions, organizations and officials to provide everyone the opportunity to get acquainted with documents, decisions and other, the norms on the possibility of 
obtaining information are enshrined in the legislation and the provision of relevant materials through publication and dissemination[14].

Consequently, the creation of the possibility of obtaining information also contributes to a decrease in the number of court cases, since the decision of the court on the case or the fact that it issued a judgment prevents appeals to the court on the same case. The announcement of the decision of the court of appeal encourages judges to clearly base their decisions on the case. Because the decision made by him can be criticized either by the press or by scientists and analysts. The principle of openness and transparency of the case in court serves to ensure that court decisions are taken reasonably, legally and fairly.

In this regard, as the First President I.A.Karimov rightly pointed out, the reputation of the state, the reputation of society depends on the compliance of the judiciary and judges with the rule of law, the compliance of their decisions with the standards of justice[15]. Therefore, in order to ensure the legitimacy, validity and fairness of the decisions of the court, which are considered a document of justice, it is important to ensure its openness and transparency of court decisions.

In the legal literature, such concepts as openness, transparency of the court proceedings are used simultaneously. For example, according to A.K.Gorbuza, the term "openness" is used in most cases to refer to court decisions, on the other hand, as a state body to the courts, and the term "transparency" is applied to the judicial process[16].

According to V.I.Anishina, the concept of the principle of transparency is ambiguous, and the terms used in this principle ("openness", "transparency") are very close in importance, but not exactly, each of which is a part of the judiciary and one aspect of its activities[17]. E.G.Fomenko argues that "transparency" is an integral part of openness, while transparency is a relatively broad concept that encompasses both openness and transparency[18]. Lawyer D.Yu.Khabibullaev also notes in his research that the transparency of judicial proceedings is a sign of democracy, on the one hand, and a way for the population to control the observance of constitutional principles in court[19].

Analysis shows that transparency should be seen as a constitutional principle of litigation that is enshrined in all procedural codes. Openness should serve to ensure access to information about the judiciary, which guarantees the constitutional right of everyone to seek, receive and disseminate information of their choice (the first part of Article 29 of the Constitution of the Republic of Uzbekistan).

From the resolution of the Supreme Court of the Republic of Uzbekistan dated February 21, 2020 № 04 “On ensuring transparency of judicial proceedings and the right to information on the activities of courts", it is possible to see that the above two concepts, namely, the issues of transparency of judicial proceedings and the right to information on the activities of courts (openness), are two different concepts. However, in the explanations given by the decision of this Plenum, the ratio between these two concepts, that is, the transparency of judicial proceedings and the openness of the activities of the courts is not clearly defined. This can also be seen from the explanation in Paragraph 1 of this Plenum decision. It explains that the transparency of judicial proceedings, timely and objective information to the public about the activities of the courts makes it possible to increase the level of legal awareness in the society, is an important 
guarantee of the implementation of justice, is an effective means of ensuring public control over judicial activities and increasing public trust in relation to the court. As we see, in this explanation, the importance of obtaining information about the activities of the courts and the transparency of judicial proceedings is explained, however, the mutual ratio of these concepts is not clearly defined.

Regarding the openness of the judiciary, the Decree of the President of the Republic of Uzbekistan dated July 13, 2018 "On measures to further improve the judicial system and increase trust in the judiciary" PF-5482[20] clearly defines the purpose of increasing the openness of the judiciary. According to it, increasing the transparency of the judiciary will serve, firstly, to further ensure the transparency of the judiciary, secondly, to expand open dialogue with the public, and thirdly, to strengthen the role of the public in the administration of justice.

In turn, the Decree provides for the following forms of increasing the openness of the judiciary to achieve these goals:

- gradual introduction of the procedure for systematic publication of court decisions on the website of the Supreme Court of the Republic of Uzbekistan;

- introduction into judicial practice the explanation of the content of the adopted judicial document to the participants of the judicial process after its announcement;

- organization of quarterly briefings by chairmen of regional courts and their deputies in order to inform the public and the media about the activities of the courts;

- quarterly publication of reviews of the practice of judicial review of cases by the judicial boards of the Supreme Court of the Republic of Uzbekistan in the supervisory procedure, the appellate and cassation proceedings by regional and equivalent courts.
As we can see, increasing the transparency of the judiciary and ensuring the right to information on the activities of the courts differs in essence from the transparency of the trial. However, some legal scholars and practitioners often do not pay attention to the specific features and aspects of these two concepts, and do not distinguish them from each other. For example, according to S.V.Potapenko, access to information on the activities of the courts can be provided by the following means: participation in an open court session; receiving (publishing) information on the activities of the courts from the media; posting data on the Internet; placement of information in court buildings; to get acquainted with the data of archival funds; provide information on request[21]. In our opinion, the transparency of the trial is a constitutional principle. In particular, Article 113 of the Constitution of the Republic of Uzbekistan stipulates that all courts may hear cases openly, and hearings in closed sessions may be allowed only in cases provided by law[22]. Based on this principle, the procedural codes of the country (CCP, CEP, $C P C, C A P$ ) determine the basis and procedure for decision-making in closed court.

Therefore, the principle of transparency determines the conduct of court proceedings, the order of court proceedings and court hearings. Consequently, the principle of transparency of judicial proceedings in civil procedural law confirms our view that this area of law is simultaneously included in the organizational and functional principles[23] that determine the structure of the court and the judicial process.

As K.F.Gutsenko rightly points out, the essence of the principle of transparency is to give all citizens who are not participants in the process the opportunity to participate in court. This should, in theory, contribute to a democracy of justice; giving citizens the 
opportunity to be in the building where the trial is taking place is a kind of public control over justice, calling the court to discipline, forcing them to be more responsible in resolving issues, everything that happens in court is as reliable and reasonable as possible[24].

As we can see, in contrast to transparency in the procedural sense, the openness of court proceedings ensures, first and foremost, access to information about the activities of the courts. In the form of a network of Internet sites is reflected in the creation and functioning of the information space of the judicial system[25].

\section{COCLUSION}

In our opinion, the content of the transparency of judicial proceedings includes the following personal rights and freedoms of subjects of civil society: a) the right to participate in judicial proceedings; $B$ ) the right to receive information in electronic or documented form in connection with the administration of fair trial; C) the right to record such information in the form established by law. Also, the content of the transparency of the fair trial includes the obligations of the competent state bodies to provide citizens with information reflecting the fair trial and not to interfere with the implementation of these rights of the subjects of civil society.

Given the mutual similarity of such concepts as openness, transparency in judicial proceedings, among others, in our opinion, for the convenience of using these terms, it is worth noting that some of them should be left in circulation and reduced to a minimum. In our opinion, it would be appropriate to use the term of transparency in relation to the judicial discussion, and the term of openness in relation to the activities of the court as a state body, with the aim of creating convenience in the use of each term in its place, as well as for the correct application of the terms.

\section{REFERENCES}

1. The Constitution of The Republic of Uzbekistan. - Tashkent, Uzbekistan. 2019. - p.5.

2. Decree of the President of the Republic of Uzbekistan No. PF-4947 "On the strategy of further development of the Republic of Uzbekistan" dated February 7, 2017 // Collection of Legislation of the Republic of Uzbekistan, February 13, 2017, No. 6, Article 70.

3. Mamasiddiqov M.M. Civil procedural law. General section / Textbook for university students. doctor of legal sciences, Professor. O.Oqyulov. -Tashkent: TSUL Publishing House. 2010. - p.p.67-68.

4. Ўзбекистон Республикаси Президенти Шавкат Мирзиёевнинг Олий Мажлисга Мурожаатномаси // Халқ сўзи, 2017 йил 22 декабрь сони.

5. The law of the Republic of Uzbekistan "On courts" in the new edition // https://www.lex.uz/acts/68532

6. Code of Civil Procedural of the Republic of Uzbekistan https://lex.uz/docs/3517337

7. Economic Procedural Code of the Republic of Uzbekistan // https://lex.uz/docs/3523891

8. Criminal Procedural Code of the Republic of Uzbekistan // https://lex.uz/docs/11146o

9. Shoraxmetov Sh.Sh. Civil procedural law of the Republic of Uzbekistan. - Tashkent, Justice. 2001. - $36 \mathrm{p}$.

10. Shoraxmetov Sh.Sh. Comments on the Code of Civil Procedure of the Republic of Uzbekistan. - Tashkent: TSUL Publishing House, 2010. P.28. 
11. Mamasiddiqov M.M. Civil procedural law. General section / Textbook for university students. doctor of legal sciences, Professor. O.Oqyulov. - Tashkent: TSUL Publishing House. 2010. - p.p.67-68.

12. Shoraxmetov Sh.Sh. Civil procedural law of the Republic of Uzbekistan. - Tashkent, Justice. 2001. - 36 p.

13. Гражданское процессуальное право: Учебник / С.А.Алехина, В.В.Блажеев и др.; Под ред. М.С.Шакарян. - М.: ТК Велби, Изд-во Проспект, 2004. -47 с.

14. Law of the Republic of Uzbekistan "On guarantees and freedom of access to information" of April 24, 1997 // Bulletin of the Oliy Majlis of the Republic of Uzbekistan, 1997, No. 4-5, Article 108; 2001, No. 1-2, Article 23; 2015, No. 52, Article 645.

15. Каримов И.А. Хозирги босқичда демократик ислохотларни чуқурлаштиришнинг мухим вазифалари. Янгича фикрлаш ва ишлаш давр талаби. Т. 5. -Тошкент: Ўзбекистон. 1997. -Б. 109, 118, 126-128.

16. Горбуз А.К. Доступность судебного решения // Российская юстиция. 2001. № 1. - С. 36.

17. Анишина В.И. Принцип гласности, открытости и транспарентности судебной власти: проблемы теории и практики реализации // Мировой судья. 2006. № 11. - С. 21.

18. Фоменко Е.Г. Принцип публичности гражданского процесса: истоки и современность. Автореф. дис. на соискание уч. ст. канд. юр. наук. Томск, 2006.

19. Xabibullaev D.Yu. Constitutional principles of civil procedural law. Textbook // Edited by Sh.Sh.Shorakhmetov. -Tashkent: TSU, 2006. -65 p .; Xabibullaev D.Yu. Principles of civil procedural law and problems of their application in judicial practice. Yurid. an abstract written for the degree of candidate of sciences. -Tashkent: TSU. 2007. p-18.

20. National Database of Legislation, 14.07.2018, No. 06/18/5482/1506

21. Потапенко С.В. Значение открытости и гласности судопроизводства для повышения уровня доверия к судебной власти // Актуальные проблемы развития гражданского законодательства на современном этапе.: сб. научн. ст. по материалам Всерос. науч.-практ. конф., 28 февраля 2014 г. / ред. кол.: А.В. Герасимов и др. Краснодар, Краснодарский ун-т МВА России, 2014. -С. 24-30.

22. Constitution of the Republic of Uzbekistan. -Tashkent, Uzbekistan. 2019. $36 \mathrm{p}$.

23. Мамасиддиқов М.М., Ёдгоров Х.Б., Давлетов Ў.М. Фуқаролик процессуал хуқуқи. Умумий қисм / Дарслик. Масъул мухаррир ю.ф.А., проф. М.Х.Рустамбаев.

-Тошкент. ХТИ нашриёти. 2018. - 556.

24. Гуценко К.Ф. Правоохранительные органы: учебник. -2-е изд., испр. и перераб.

-М.: КНОРУС, 2013. - С. 98.

25. Подняков М.Л. Практическая реализация принципа открытости правосудия в Российской Федерации // СПб.: Институт проблем правоприменения при Европейском университете в Санкт-Петербурге, 2013. -С.2. 